\title{
FADO SOSTENIDO EN MÍ MAYOR
}

\author{
SHARP FADO IN MAJOR ME
}

Patricia Rojo Lemos*

\section{Oporto}

Oporto es un otoño de consonantes cambiadas, la decadencia disfrazada de tristeza, de alegría embotellada.

Un invierno estival de azulejo, de subidas empinadas de hojas de parra por caer, casas de puntillas y lágrimas salobres.

Un regusto a vino húmedo con sinsabores, El abrazo que te robé en una freguesía algo marginal y los besos que me diste entre tantas palabras mascadas.

Francesinhas, cachorros y torradas con las que soñabas entre sábanas, esas que te alimentaban cada día con un café frente al predio abandonado.

Toda la saudade contagiosa que empaña sus calles y recorre sus fados.
Los días sin fuerza heredados a golpe de verso, de llanto contenido y cualquier futuro posible quebrado.

\section{A noite é uma criança}

La noche portuense

é uma criança,

de bocas hambrientas armadas de nostalgias letales, de pesadillas sedientas de un poco de bondad.

La noche portuense se contiene en un llanto sin cuna desbocado calle abajo. Tantas miradas claras de corazón pequeño teñidas de sangre de luna.

Tú también llevabas la noche dentro:

Te quise a oscuras palpando nuestras soledades,

* Universidad Alfonso X el Sabio, Facultad de Lenguas Aplicadas y Universidad Politécnica de Madrid, España.

** Traducción: Lic. Geannette Soto. Escuela de lenguas Modernas. Universidad de Costa Rica. Correo electrónico: patricia.rojo.lemos@gmail.com Recepción:08/05/13. Aceptación:29/05/13. 
un amor atlántico

sin costa, sin dulzura.

La noche muere en cada sensatez, en cada palabra repetida;

por nacer la luz cabal, mi abandono, por sentir tu razón, mi despedida.

\section{Plaza de la Batalha}

Hundo mi grito en tu plaza

y me atrinchero en la razón.

Mi lógica fluye salvaje

a la espera de verte caer.

Resisto tus miradas etílicas.

A la mitad de la noche,

mi voz afoniza;

mi bandera no es más

que un estandarte de dignidad hilarante.

La humedad de tu llanto me suplica

que te quiera en tu locura.

Loca, yo también,

me callo, me ato, me agacho,

firmo mi rendición.

He perdido mi batalla

y tú has ganado tu guerra.

\section{Luscofusco}

Odié la luz cuando escoció mis lágrimas y proyectó tu sombra encorvada lejos de la mía. Una calle cualquiera me despide de nosotros mientras la luz gana por fotones a tu olvido. Me preparé entonces para la norma y el sosiego; me compuse sin resistirme al hastío al porvenir de tardes mordiendo tu indiferencia, expulsando $\mathrm{CO} 2$ de cordura, rumiando memorias dulces que no cicatrizan. Una vida en un crepúsculo que se agota resplandeciente para dar paso al día.

Ese instante de bisagra rota no me deja amanecer ni oscurecerme, no quiere que te encierre.

\section{Mi amo y señor}

A ti, Miguel, que me diste un yoyo de cariño

Mi amo y señor no ordena, sentencia solemne entre humo; apura la vida que le sobra y estropea los muchos recuerdos con la soberbia del indolente. Quiere con desdén.

Ama sin futuro.

Fuma sin salud ni enfermedad, se ausenta de todo presente, mastica los sueños, reivindica su fado sostenido mientras hace de la tristeza costumbre.

Mi amo es esclavo del olvido, muere sin prisa en el desapego.

Por cada empeño estoico de valentía, derrama un Duero de soledad sentida. Mi amo y señor envuelve sentimientos con seriedad y poco consuelo.

Vive entre la penumbra decimonónica y un disfraz curtido de tanta despedida. Busca sin querer encontrar otro amo que tampoco ordene con quien compartir desarraigos y condenar todo lo que quiere.

Mi amo y señor mira de frente y vive de lado, se arrastra con dulzura bajo un sombrero y unas penas que ya no recuerda.

Mi amo no me merece, no percibe mi desasosiego:

a veces sonríe y yo me someto.

\section{Incandescente}

Una y otra vez volverá mi mente a tus sábanas; no dejaré de temblar ese abrazo

En los abrazos de fuego se pierden los amantes y los recuerdos. Se quema el alma y enciende la sed. Luego, esa ausencia de piel 
desencadena el dolor contenido, el que no cabe en ese instante que no será, ni tiene presente.

Después, solo la deriva.

La certeza fiel de la deriva

que irá secando el llanto

y llenará de sal los pulmones

mientras el viento aviva la herida.

El tiempo sopla, empuja, aleja cualquier

esperanza

de saber en qué gastar las lágrimas, cómo justificar el vacío de lo que nunca llenamos.

Seguir perdiendo el consuelo, brotando sin fin, no intuir el adiós no pronunciado,

ni soñar sin ti aunque ya no contigo.

Invadirse de una calma triste irreparable...

Tu silencio ahumado en forma de bruma...

Ya no arde el deseo, pero sí abrasa, tanto, que pienso que aún te quiero.

\section{Lejos}

Hay noches que te pienso con distancia y tan lejos que sé que no podré volver.

Otros días, en cambio, te lloro hasta secarme, me rodeas en una bruma atemporal; me humedece pensarte, te siento cerca. Desnuda y sola, tal como me dejaste, desnuda frente al espejo de mis prejuicios; sola, apartada de ellos.

Un poco atemorizada porque no volverán a arroparme, ni tampoco lo harán tus brazos o mis abrazos. Desnuda, sola, atemorizada, pero despierta y triste, muy triste, con la tristeza del adiós que espera ser hasta pronto, pero solo recibe el eco.

Mi voz que reverbera en el espejo.

\section{Eco}

Algún día saldrás de tu lamento hueco que tanto resuena a cerrado. Dejarás tu laberinto circular de sombras y caminarás con tiento hacia la luz, como el que espera la vida.

Te librarás de esa trampa de libertad para caer en la mediocridad que tanto te asusta. Ese hecho tan vulgar tendrá cadencia de mujer, aunque ya no te arrullen mis senos, ni mi voz aliente el olvido.

\section{Pálpito}

Latidos, sístole:

tu sangre a mi herida.

Barro, sol, sudor y vino.

Cristales rotos de cordura.

Nocturnidad sin freno.

Amor a quemarropa,

desazón desnuda

Aliento quebrado.

Exhalación, diástole:

vista rota,

frente a la pared.

Dolor a raudales.

Ceguera silente.

Y tú que no cesas.

\section{Querida Saudade:}

Me cansé de agradarte, de acomodarme a tus gustos de honrarte en el delirio y sacrificar mis noches a tu causa triste.

Jodida y muy triste.

Eres una proxeneta

— dicho así con finurade mis ilusiones.

¿No te aburres de antagonizar porvenires, de enlutar sueños, de ridiculizar logros?

No conoces límites.

Allá donde surge un hilo de luz acudes rauda a ensombrecerlo.

Te llevas más vidas que la parca; en tu camino umbrío guareces al deslumbrado, al quemado por la intensidad. Tu paso suave alcanza al más lento, nunca cuestionas, solo ofreces.

Mi puta amiga nostálgica, quiero poder echarte en falta. 
